\title{
PENINGKATAN KUALITAS GURU SDN 49 TERNATE DALAM PENGEMBANGAN INDIKATOR PENCAPAIAN KEBERHASILAN PADA SILABUS MELALUI POS PELATIHAN SEDERHANA TAHUN PELAJARAN 2017/2018
}

\author{
SOFYAN MUHAMMAD NUR
}

Kepala SD Negeri 49 Kota Ternate, Kelurahan Tabam Kecamatan Kota Ternate Utara

Author Correspondence: sofyan_mnur@yahoo.com

$\begin{array}{ll}\text { Diterima } & : 20-09-2019 \\ \text { Direvisi } & : 30-10-2019 \\ \text { Dipublikasi } & : 05-11-2019\end{array}$

ABSTRAK: Pada saat peneliti mengadakan supervisi akademik, ada beberapa hal yang peneliti temui, diantaranya guru belum mampu mengembangkan Indikator Pencapaian Keberhasilan pada silabus, jika indikator pencapaian keberhasilannya belum mampu dibuat oleh guru, maka akan berdampak pada proses pembelajaran di kelas. Untuk meningkatkan pemahaman guru tentang pembuatan indikator pencapaian keberhasilan dengan benar, maka melalui pos pelatihan sederhana dalam Kelompok Kerja Guru (KKG) menjadi salah satu alternatif dan bisa menjadi solusi untuk perbaikan-perbaikannya. Prosedur pelaksanaan penelitian tindakan yang dilakukan melalui empat tahapan, yaitu perencanaan (planning), pelaksanaan tindakan (acting), pengamatan (observing), dan refleksi (reflecting), dan dilaksanakan dalam 2 siklus. Hasil pada sikulus I rata-rata pemahaman guru tentang KKO dan penggunaannya dalam pengembangan indikator masih kurang (36\%). Demikian juga ratarata kemampuan guru kelas dalam pengembangan indikator masih kurang (38,50\%). Penelitian dilanjutkan ke siklus II, hasilnya terlihat ada rata-rata peningkatan pemahaman mereka (guru) tentang KKO dan penggunaanya dalam pengembangan indikator tersebut, dari $36 \%$ menjadi $81 \%$, dan pengembangan indikator dalam penyusunan silabus meningkat, yakni dari rata-rata $38,50 \%$ (Siklus I) menjadi $76 \%$. Dan rata rata prosentase aktivitas guru dalam kegiatan pengembangan indikator juga meningkat dari $81,60 \%$ (siklus I) menjadi $94 \%$ (siklus II). Para guru menyambut baik program kegiatan pengembangan indikator ini dan menyatakan kepuasan dengan kegiatan di forum ini.

Kata Kunci: Peningkatan kualitas Guru, indikator pencapaian keberhasilah, Kelompok Kerja Guru (KKG)

\section{PENDAHULUAN}

Perkembangan pendidikan di sekolah dasar masih banyak mengalami permasalahan mendasar, salah satunya kemampuan guru profesionalisme dalam menjalankan tugasnya. Mengingat fungsi guru yang demikian strategis untuk menghasilkan lulusan yang lebih bermutu maka sekolah dituntut untuk senantiasa mengembangkan kemampuan para gurunya lewat berbagai cara.Salah satu diantaranya adalah meningkatkan proses belajar mengajar. Proses pembinaan guru tidak lepas dari tuntutan kemajuan ilmu pengetahuan dan teknologi yang begitu pesat saat ini. Tuntutan kemajuan (standar kompetensi, kompetensi dasar dan materi pelajaran) bagaimana cara mengajarkannya (pengalaman belajar, metode dan media) dan bagaimana mengetahui pencapaiannya (evaluasi dan sistim penilaian).

Konsep pengembangan guru melalui kegiatan Kelompok Kerja Guru (KKG) berorientasi pada proses. Artinya proses menuju guru professional mendapat perhatian penuh. Guru dipandang sebagai individu yang dapat berkembang jika terjadi proses internal untuk berkembang dalam diri guru tersebut, sangat dipengaruhi oleh proses eksternal yaitu dorongan dari luar. Proses internal akan tumbuh jika guru masuk dalam jangkauan informasi terus menerus,kemauan berkembang ini akan mengantar guru untuk mencari teman seprofesinya atau kelompok guna sharing dan berdiskusi.

Harapan ini belum nampak.khususnya pada guru SD Negeri 49 Kota Ternate sekolah yang saya pimpin. Sekolah ini berdiri pada tahun 1968 dan sebagai salah satu sekolah negeri yang terletak di kelurahan Tabam termasuk dalam administrasi Kecamatan Ternate Utara, Kota Ternate. Saat ini SD Negeri 49 Kota Ternate memiliki siswa sejumlah 251 orang dengan fasilitas ruang kelas sebanyak 9 Ruang, 1 
perpustakaan, 1 ruang guru dan kepala sekolah serta mempunyai rombongan belajar sebanyak 12 Rombel. Sedangkan jumlah pegawai sebanyak 16 orang dengan rincian guru negeri sebanyak 12 orang, guru honor sebanyak 2, Tata Usaha sebanyak 1 orang dan penjaga sekolah 1 orang. SD Negeri 49 Kota Ternate merupakan SD Inti yang membawahi beberapa SD Imbas, diantaranya SD Negeri 48,SD Negeri 50, dan SD Negeri 54.Sebagai Sekolah Inti, maka SD Negeri 49 harus lebih baik dibandingkan dengan Sekolah imbas.

Kualitas pendidik yang melaksanakan tugas di Sekolah tersebut dituntut harus lebih baik.Guru harus memiliki pemahaman, kesadaran,kemampuan ,kreatifitas kesabaran dan keuletan Dalam Mengelola Pembelajaran.Ini belum terlihat ketika Kepala Sekolah Mengamati beberapa guru dalam melaksanakan kegiatan Pembelajarannya. Pada saat peneliti mengadakan Superfisi Akademik, ada beberapa hal yang peneliti temui, diantaranya guru belum mampu membuat Indikator Pencapaian Keberhasilan pada silabus, jika Indikator Pencapaian Keberhasilan nya belum mampu dibuat oleh guru,, maka akan berdampak pada proses pembelajaran di kelas. Untuk meningkatkan pemahaman guru tentang pembuatanIndikator Pencapaian Keberhasilan dengan benar, maka melalui Kelompok Kerja Guru (KKG) menjadi salah satu alternative dan bisa menjadi solusi untuk perbaikan-perbaikannya. Untuk itu penulis member judul " Peningkatan Kualitas Guru SDN 49 Ternate dalam Pengembangan Indikator Pencapaian keberhasilan pada silabus melalui pos pelatihan sederhana tahun 2018 ".Kepala sekolah dapat beperan positif terhadap perkembangan para guru, yaitu para kepala sekolah harus mampu meningkatkan potensi guru-guru sekaligus memberikan ruang gerak dan kebebasan untuk maju bagi para guru guna meningkatkan komitmen tanggung jawab tugasnya.Para guru perlu mendapatkan dorongan kuat dari para kepala sekolah untuk berani keluar dari dunia rutinitas hariannya masuk kedalam dunia dinamis yang merupakan syarat dari sutau perkembangan profesionalisme para guru itu sendiri dalam rangka meningkatkan kompetensi untuk mendukung tugas luhurnya sebagai guru yang profesional. Sebaliknya kepala sekolah dapat menjadi penghambat perkembangan para guru, jika para guru tidak mendapat dukungan untuk secara dinamis mengembangkan potensinya dengan berinteraksi dengan jaringan guru-guru dari satuan pendidikan lainnya dan lembaga-lembaga lainnya. Dengan interaksi keluar yang terarah maka para guru akan mendapatkan berbagai bestpractices dari jaringannya sehingga individualnya akan terbangkitkan untuk maju bersama rekan guru lainnya.

Tulisan ini akan lebih memfokuskan pembahasan dari aspek guru atau pendidik, yakni Upaya-upaya apa saja yang harus ditempuh pemerintah dan pihak-pihak yang terkait untuk meningkatkan mutu pendidik dan tenaga kependidikan. Dan strategi bagaimanakah meningkatkan mutu pendidik dan tenaga kependidikan. Upaya peningkatan mutu pendidikan dipengaruhi oleh faktor majemuk. Faktor yang satu saling berpengaruh terhadap faktor yang lainnya. Namun demikian, faktor yang paling penting adalah guru, karena hitam-putihnya proses belajar mengajar di dalam kelas banyak dipengaruhi oleh mutu gurunya. Guru dikenal sebagai 'hidden currickulum' atau kurikulum tersembunyi, karena sikap dan tingkah laku, penampilan profesional, kemampuan individual, dan apa saja yang melekat pada pribadi sang guru, akan diterima oleh peserta didiknya sebagai rambu-rambu untuk diteladani atau dijadikan bahan pembelajaran. Bagi sebagian besar orangtua siswa, sosok pendidik atau guru masih dipandang sebagai wakil ora orangtua ketika anak-anaknya tidak berada di dalam keluarga.

\section{METODE PENELITIAN}

Peneletian Tindakan Sekolah (PTS) merupakan penelitian yang dilakukan oleh Kepala Sekolah sesuai dengan tugas profesional Kepala Sekolah, yaitu membina guru melalui Pos Pelatihan Sederhana, sehingga tindakan yang dilakukan dan diteliti adalah memberikan pembinaan terhadap guru secara keseluruhan (Dirjen PMPTK Depdiknas, 2007:20-21).

Penelitian Tindakan merupakan suatu bentuk penelitian yang bersifat reflektif dengan melakukan tindakan tertentu agar dapat memperbaiki/meningkatkan kualitas sekolah secara profesional. Penelitian ini lebih memfokuskan kepada pengembangan indikator dalam penyusunan silabus melalui pelatihan sederhana di Kelompok Kerja Guru. 
Prosedur pelaksanaan penelitian tindakan yang dilakukan melalui empat tahapan, yaitu perencanaan, pelaksanaan, pengamatan harus melalui beberapa tahapan, yakni perencanaan (planning), pelaksanaan tindakan (acting), pengamatan (observing), dan refleksi (reflecting) (Dirjen PMPTK Depdiknas, 2007:20-21). Keempat tahapan penelitian yang merupakan komponen kegiatan pokok dari sebuah siklus PTS dapat digambarkan sebagai berikut:

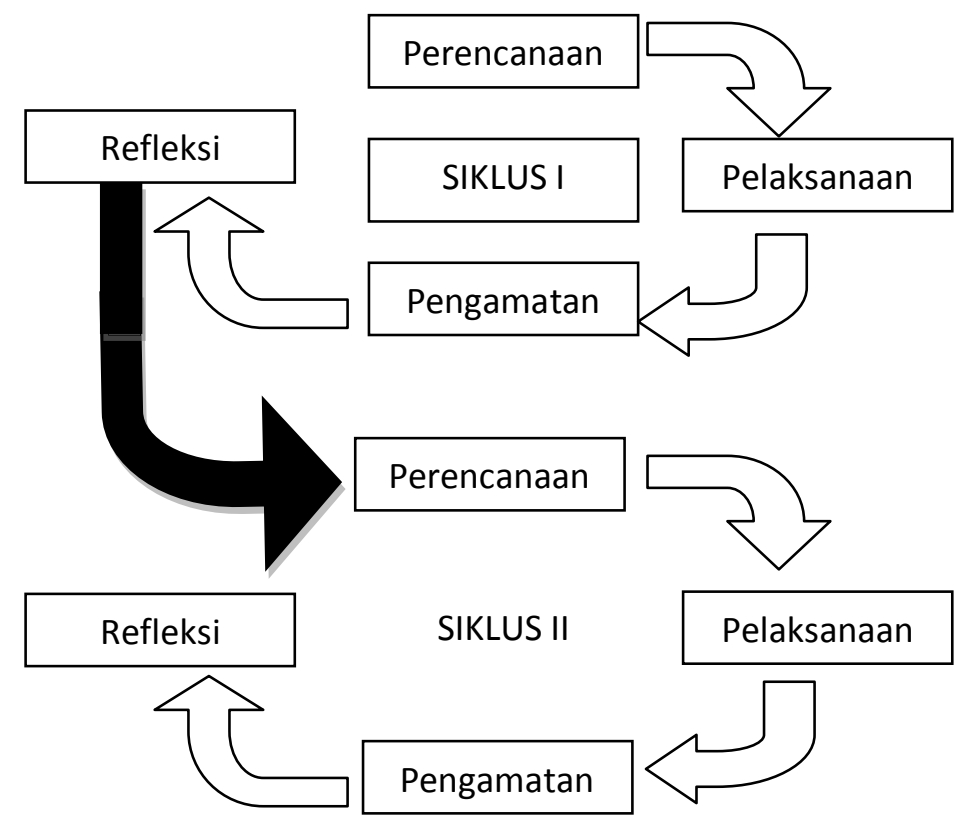

Gambar 1. Model Penelitian Tindakan Sekolah (Depdiknas, 2007:29)

\section{Setting dan Subyek Penelitian}

Sekolah yang dijadikan tempat penelitian adalah SD Negeri 49 Kota Ternate dengan jumlah guru sebanyak 10 orang. Penelitian ini dilaksanakan pada bulan Maret 2018 bertempat di SDN 49 Kota Ternate. Subjek penelitian adalah seluruh guru kelas dan Guru Mata Pelajaran.

Aktifitas penelitian dipusatkan pada pengamatan terhadap kegiatan guru dalam memahami dan merumuskan/mengembangkan indikator pada pengembangan silabus. Hasil kegiatan pengamatan tersebut kemudian dianalisis dan diolah untuk mengetahui tingkat ketercapaian pemahaman guru dalam mengembangkan indikator pada pengembangan silabus .

\section{Pengembangan Indikator dan Instrumen Penelitian}

\section{Pengembangan indikator}

Pengembangan indikator yang dimaksud dalam penelitian ini adalah pengembangan indikator untuk mata Pelajaran di Sekolah Dasar. Ada beberapa langkah yang peneliti lakukan dalam membina dan membimbing guru dalam pengembangan indikator, yaitu menelaah indikator pada silabus yang sudah dibuat terdahulu, mengecek pemahaman guru tentang maksud perumusan indikator dan kriteria indikator, mengecek pemahaman guru tentang kata kerja operasional (KKO), menganalisis Standar Kompetensi dan Kompetensi Dasar, menyusun indikator sesuai kriteria.

\section{Instrumen Penelitian}

Pada penetian ini penulis menggunakan instrumen penelitian berupa lembar observasi, terhadap pemahaman guru tentang perumusan/pengembangan indikator dan aktivitas guru selama kegiatan dimaksud dalam KKG. 


\section{Kriteria Keberhasilan}

Kriteria keberhasilan dalam penelitian tindakan sekolah ini adalah meningkatnya prosentase pemahaman guru dalam penyusunan indikator, yang ditandai dengan terwujudnya indikator yang memenuhi kriteria.

\section{Prosedur Penelitian}

Prosedur penelitian yang dilakukan peneliti adalah sebagai berikut:

1. Perencanaan

a. Menganalisis/mengobservasi silabus seluruh mata pelajaran yang sudah ada;

b. Menetapkan objek yang dijadikan sasaran penelitian tindakan sekolah yaitu perumusan / pengembangan indikator untuk mata pelajaran.

c. Melaksanakan pertemuan awal dengan seluruh guru.

d. Menginventarisir dan mengkaji masalah yang dihadapi guru dalam merumuskan / mengembangkan indikator secara umum.

e. Membuat lembar observasi dan model pengembangan indikator.

f. Menyusun bahan bimbingan untuk guru berupa kumpulan kata kerja operasional, dan format silabus.

2. Tindakan, Pengamatan, dan Refleksi

a. Siklus I

1. Melaksanakan kegiatan pengembangan indikator dengan menggunakan model pengembangan indikator yang telah disusun;

2. Selama kegiatan KKG berlangsung, dilaksanakan pengamatan/observasi;

3. Melakukan refleksi atas tindakan yang telah dilaksanakan tentang pemahaman guru dalam merumuskan indikator sebagai bahan untuk digunakan pada siklus kedua.

b. Siklus II

1) Melaksanakan kegiatan pengembangan indikator dengan menggunakan model pengembangan indikator yang telah disusun;

2) Selama kegiatan KKG berlangsung, dilaksanakan pengamatan/observasi;

3) Melakukan refleksi atas tindakan yang telah dilaksanakan tentang pemahaman guru dalam merumuskan indikator;

4) Menelaah/menganalisis semua data yang telah terkumpul;

5) Pengkategorian dan pengklasifikasian data;

6) Membuat kesimpulan;

7) Refleksi dari semua tindakan yang telah dilakukan.

\section{Teknik pengumpulan data}

Pengumpulan data dilakukan secara Kualitatif dan Kuantitatif. Penelitian kualitatif, yaitu pengumpulan data melalui pengamatan aktivitas guru, yang berorientasi pada perencanaan pembelajaran tentang pengembangan indikator dalam menyusun silabus, sedangkan secara kuantitatif, yaitu menganalisis hasil kegiatan pengembangan indikator.

\section{Pengolahan data}

Data yang diperoleh dianalisis dengan merujuk pada teknik analisis yaitu interpretasi data hasil observasi, dan hasil analisis pelaksanaan kegiatan pengembangan indikator. 


\section{HASIL PENELITIAN}

\section{Siklus I}

\section{Pemahaman Guru tentang KKO dan Penggunaannya dalam Pengembangan Indikator}

Penyebab kurangnya pemahaman guru tentang pengembangan indikator, antara lain adalah kurangnya pemahaman terhadap penggunaan kata kerja operasional (KKO) sebagai salah satu ciri keterukuran dari sebuah indikator. Oleh karena itu, pengertian indikator dan penggunaan KKO yang tepat harus dipahami terlebih dahulu oleh guru, sebelum ke pelaksanaan pengembangan/penyusunan indikator.

Selama kegiatan Siklus I berlangsung, dilaksanakan observasi. Berdasarkan hasil observasi tersebut diperoleh data Rata rata prosentase pemahaman guru tentang KKO dan penggunaannya dalam pengembangan indikator mencapai $36 \%$, hal ini berarti kualifikasi pemahaman guru tentang KKO pengembangan indikator kurang, seperti tampak pada Tabel 3.

Hasil penelitian pemahaman guru tentang KKO dan ketepatan penggunaannya dalam pengembangan indikator baru mencapai $40 \%$, artinya masih ada guru yang belum benar-benar memahami KKO dan penerapannya. Sementara itu, pemahaman guru dalam sistematika pengembangan indikator masih kurang (28\%), artinya rata-rata guru belum mampu untuk mengembangkan indikator sesuai dengan kriteria.

\section{Kemampuan Guru dalam Pengembangan Indikator}

Observasi terhadap kemampuan guru pada pengembangan indikator dalam penyusunan silabus, dilaksanakan selama kegiatan Siklus I berlangsung. Hasil observasi terhadap kemampuan guru dalam pengembangan indikator diperoleh data Rata rata prosentase kemampuan guru dalam pengembangan indikator baru mencapai $38,50 \%$, artinya kualifikasi pemahaman guru tentang pengembangan indikator kurang, seperti tampak pada Tabel 4.

Kurangnya kemampuan guru dalam mengembangkan indikator sesuai karakteristik peserta didik (28\%), karena mereka (guru) kurang memahami KKO dan penerapannya dalam mengembangkan indikator berdasarkan aspek pengetahuan, keterampilan dan sikap. Guru kurang memahami KKO yang tepat sesuai dengan tingkat berpikir siswa, rata-rata mengembangkan indikator mengambil dari kriteria kinerja dalam deskripsi pembelajaran pada kurikulum.

Ketercapaian kemampuan guru dalam mengembangkan indikator sesuai karakteristik mata pelajaran dan satuan pendidikan, baru mencapai $30 \%$ (kualifikasi cukup). Berdasarkan hasil penelitian, masih ada beberapa guru yang belum memahami karakteristik setiap mata pelajaran. Guru mengembangkan indikator melalui analisis terhadap standar kompetensi (SK) dan kompetensi dasar (KD) tetapi belum maksimal. Berdasarkan hasil observasi, indikator dikembangkan hanya menganalisis SK/KD (Standar Isi) saja, sedangkan Standar Kompetensi Lulusan (SKL), Standar Pengelolaan, Standar Penilaian, Standar Proses, dan standar lainnya kurang atau belum mendapat perhatian. Pada Pengembangan Indikator sesuai dengan Satuan Pendidikan masih berada pada kisaran 36\%.

Demikian juga dengan tingkat/keterukuran indikator, pengembangannya baru mencapai 30\% (kualifikasi cukup), dan ketepatan serta kejelasan indikator baru mecapai 30\% (kualifikasi kurang), hal ini sangat erat kaitannya dengan pemahaman guru tentang KKO dan penggunaannya/penerapannya.Jadi jelaslah bahwa guru belum mampu mengembangkan indikator sesuai kriteria indikator yang diharapkan (baik), sehingga keberhasilan pembelajaran juga belum maksimal.

\section{Aktivitas Guru dalam Kegiatan Pengembangan Indikator}

Semua Guru yang berjumlah 10 orang dikumpulkan di ruang yang dinamai "Popeda Sagu“" tersebut, mereka merasa senang dengan kegiatan ini. Ini terlihat dari aktivitas guru yang terbilang tinggi. 
Pengamatan (observasi) terhadap aktivitas guru, diperoleh hasil data rata-rata prosentase aktivitas guru mencapai $81,60 \%$ dengan kualifikasi sangat baik, mereka menyambut baik program kegiatan pengembangan indikatorini, terkadang mereka beriskusi sambil berceloteh dengan bahasa daerah Ternate, "torang puas dengan kegiatan di popeda sagu " artinya kami puas dengan kegiatan di forum ini. seperti yang terlihat pada tabel 5 .

Disiplin, tanggungjawab, dan keseriusan guru dalam kegiatan pengembangan indikator sangat baik, mereka menyadari pentingnya kegiatan tersebut untuk meningkatkan profesionalisme mereka dalam menyusun perencanaan pembelajaran dan pengelolaan pembelajaran. Hanya dalam kerjasama dan keterlibatan dalam diskusi baru mencapai $78 \%$ dan $76 \%$ (kualifikasi baik), berdasarkan hasil pengamatan masih ada guru yang belum berani mengemukakan pendapatnya dalam kegiatan diskusi selama kegiatan berlangsung.

Berdasarkan data-data hasil observasi tersebut, diperoleh temuan bahwa pemahaman guru tentang KKO dan penggunaannya dalam pengembangan indikator masih kurang (36\%). Demikian juga kemampuan guru kelas dalam pengembangan indikator masih kurang (38,50\%). Data hasil temuan pada kegiatan Siklus I, menjadi dasar/acuan bagi peneliti untuk melaksanakan kegiatan Siklus II.

\section{Siklus II}

\section{Pemahaman Guru tentang KKO dan Penggunaannya dalam Pengembangan Indikator}

Berdasarkan temuan pada Siklus I bahwa pemahaman guru tentang KKO dan penggunaannya dalam pengembangan indikator kurang (36\%), maka peneliti melakukan tindakan penelitian Siklus II.Selama pelaksanaan kegiatan siklus II, untuk meningkatkan pemahaman guru tentang KKO dan penggunaannya dalam pengembangan indikator, dilakukan observasi seperti pada siklus I. Hasil observasi diperoleh data Rata rata prosentase guru tentang KKO dan penggunaannya dalam pengembangan indikator meningkat dari 36\% menjadi 81\% dengan kualifikasi baik, seperti pada Tabel 6.

Disini tampak adanya perubahan pemahaman guru tentang KKO dan penggunaannya dalam pengembangan indikator meningkat cukup tinggi, mereka mulai memahami bahwa penggunaan KKO yang tepat dalam pengembangan indikator sangat penting, karena akan mudah untuk menilai tingkat ketercapaian penguasaan siswa terhadap materi pelajaran. Demikian juga adanya perubahan yang cukup signifikan terhadap kemampuan guru dalam ketepatan, sistematika dan pengembangan indikator, mereka menyadari, bahwa pengembangan indikator dengan tepat dan sistematis akan memudahkan mereka dalam mengelola pembelajaran sehingga siswa lebih terarah dalam mencapai target/kompetensi yang harus dikuasainya.

\section{Kemampuan Guru dalam Pengembangan Indikator}

Hasil observasi dalam siklus II terhadap kemampuan guru tentang pengembangan indikator dalam penyusunan silabus meningkat, yakni dari 38,50\% (Siklus I) menjadi 76\%, seperti tampak pada Tabel 7. Berdasarkan hasil tersebut di atas, kemampuan guru dalam mengembangkan indikator sesuai karakteristik peserta didik dan karakteristik potensi daerah mengalami peningkatan yang cukup baik, mereka mulai menyadari bahwa indikator harus dikembangkan sesuai dengan tingkat berfikir siswa, bukan tingkat berpikir guru.

Demikian juga dengan kemampuan guru dalam mengembangkan indikator sesuai karateristik mata pelajaran dan tingkat satuan pendidikan meningkat. Mereka mulai memahami bahwa indikator harus dikembangkan sesuai dengan karakteristik mata pelajaran, jadi dalam mengembangkan indikator harus memperhatikan tuntutan atau standar yang ingin dicapai dari mata pelajaran tesebut.

Pengembangan indikator harus sesuai tingakat satuan pendidikan, karena tiap satuan pendidikan memiliki karakteristik yang berbeda, dan memiliki tuntutan yang berbeda terhadap lulusannya. 
Berdasarkan hasil observasi, bahwa guru mulai memahami KKO dan penerapannya serta guru memahami bahwa indikator harus dibuat berdasarkan kepentingan dan berkesinambungan melalui kegiatan menganalisis keterkaitan antar kompetensi dasar dan antar standar kompetensi, selain itu juga melalui pemetaan SK, KD.

\section{Aktivitas Guru dalam Kegiatan Pengembangan Indikator}

Observasi terhadap seluruh aktivitas guru dalam Pos Pelatihan Sederhana pada Siklus II, mengalami peningkatan yang signifikan, mereka (guru) bekerjasama dalam kelompok dengan penuh tanggung jawab dan disiplin, serta terlibat secara aktif dalam diskusi kelompok seperti yang terlihat pada tabel 8 . Rata rata prosentase aktivitas guru dalam kegiatan pengembangan indikator meningkat dari 81,60\% (Siklus I) menjadi 94\% (Siklus II).

Keterlibatan mereka dalam diskusi sangat baik, mereka cukup termotivasi untuk terlibat secara emosional.Mereka menyadari bahwa kegiatan pengembangan indikator sangat penting bagi mereka dalam meningkatkan profesionalismenya.

\section{PEMBAHASAN}

\section{Perkembangan Pemahaman Guru tentang KKO dan Penggunaannya dalam Pengembangan Indikator}

Berdasarkan hasil temuan peneliti di lapangan, bahwa guru masih ada yang belum memahami tentang pengembangan indikator dalam penyusunan silabus, melalui kegiatan bimbingan dan pembinaan yang dilaksanakan oleh peneliti dengan kajian pengembangan indikator terlihat ada peningkatan pemahaman mereka (guru) tentang KKO dan penggunaanya dalam pengembangan indikator tersebut, dari $36 \%$ menjadi $81 \%$, tampak seperti pada Tabel 9. Agar lebih jelas data pada tabel di atas, dapat kita lihat dalam bentuk grafik 1 dan 2, tentang perkembangan pemahaman guru tentang pengembangan indikator.

Rata rata prosentase pemahaman guru tentang pengembangan indikator dalam penyusunan silabus terlihat ada peningkatan, seperti tampak pada Tabel 10. Hal ini dapat terlihat dari sajian pada Gambar 2, sebagai pembanding hasil kegiatan yang dilaksanakan pada Siklus I dan Siklus II tentang pemahaman guru dalam mengembangkan indikator dalam menyusun silabus.

\section{Perkembangan Aktivitas Guru dalam Kegiatan Pengembangan Indikator}

Perkembangan aktivitas guru dalam kegiatan pengembangan indikator mengalami perubahan/peningkatan, hal tersebut dapat dilihat pada tabel 11. Lebih jelasnya, perkembangan aktivitas guru dalam pengembangan dapat dilihat dari sajian grafik 3. Data selengkapnya dapat dilihat pada tabel berikut.

Tabel 1. Teknik Pengumpulan Data

\begin{tabular}{llllll}
\hline No & Sumber Data & Jenis Data & Teknik Pengumpulan Data & Instrumen & Tempat \\
\hline 1 & Guru & $\begin{array}{l}\text { Permasalahan } \\
\text { berkenaan dengan } \\
\text { pemahaman guru } \\
\text { dalam pengembangan } \\
\text { indikator }\end{array}$ & Observasi & $\begin{array}{l}\text { Lembar } \\
\text { Observasi }\end{array}$ & KKG \\
& Aktivitas Guru & Observasi & & \\
2 & Guru & Observasi & $\begin{array}{l}\text { Lembar } \\
\text { Observasi }\end{array}$ & KKG \\
3 & $\begin{array}{l}\text { Pengembangan } \\
\text { indikator }\end{array}$ & $\begin{array}{l}\text { Gambaran } \\
\text { kemampuan membuat } \\
\text { indikator dari tiap } \\
\text { komptensi dasar }\end{array}$ & & Observasi & KKG \\
& & & & \\
\hline
\end{tabular}


Tabel 2. Penilaian Hasil Kegiatan

\begin{tabular}{lc}
\hline Nilai & Kategori \\
\hline $\mathbf{2 0 0 \%}$ & SangatBaik \\
$\mathbf{6 0 \%}-\mathbf{7 9 . 9 \%}$ & Baik \\
$\mathbf{4 0 \%}-\mathbf{5 9 . 9 \%}$ & Cukup \\
$\mathbf{2 0 \%}-\mathbf{3 9 . 9 \%}$ & Kurang \\
$\mathbf{2 0 \%}$ & Sangat Kurang \\
\hline
\end{tabular}

Tabel 3.Prosentase Pemahaman Guru tentang KKO dan Pengembangan Indikator Siklus I

\begin{tabular}{clcc}
\hline No. & \multicolumn{1}{c}{ Aspek yang diobservasi } & Prosentase & Ket \\
\hline 1. & $\begin{array}{l}\text { Pehamaman Guru tentang Kata Kerja Operasinal (KKO) dalam } \\
\text { pengembanganIndikator }\end{array}$ & $36 \%$ \\
2. & $\begin{array}{l}\text { Pehamaman Guru tentang Penggunaan KKO } \\
\text { 3. }\end{array}$ & $40 \%$ \\
& $\begin{array}{l}\text { Pehamaman Guru tentang ketepatan penulisan/ pengembangan } \\
\text { 4. }\end{array}$ & $40 \%$ \\
& $\begin{array}{l}\text { Pehamaman Guru tentang sistematika pengembangan/ } \\
\text { penyusunan indikator }\end{array}$ & $28 \%$ \\
\hline
\end{tabular}

Tabel 4. Prosentase Pemahaman Guru tentang Pengembangan Indikator Siklus I

\begin{tabular}{llcc}
\hline No. & Aspek yang diobservasi & Prosentase & Ket \\
\hline 1. & Indikator dikembangkan sesuai dengan karakteristik peserta didik & $28 \%$ \\
2. & Indikator dikembangkan sesuai dengan karakteristik mata & $30 \%$ \\
& pelajaran & $36 \%$ \\
3. & Indikatordikembangkansesuaidengansatuanpendidikan & $30 \%$ \\
4. & Indikator dikembangkan terukur dan dapat diobservasi & $30 \%$ \\
5. & Indikator dikembangkan dengan Jelas dan tepat & \\
\hline
\end{tabular}

Tabel 5. Prosentase Aktivitas Guru dalam Kegiatan Pengembangan Indikator Siklus I

\begin{tabular}{|c|c|c|}
\hline No & Aspek yang diobservasi & Prosentase \\
\hline 1. & Disiplin & $82 \%$ \\
\hline 2. & TanggungJawab & $82 \%$ \\
\hline 3. & Kerjasama & $78 \%$ \\
\hline 4. & Antusias/serius & $90 \%$ \\
\hline & Keterlibatandalamdiskusi & $76 \%$ \\
\hline
\end{tabular}

Tabel 6. Prosentase Pemahaman Guru tentang KKO dan Penggunaannya dalam Pengembangan Indikator Siklus II

\begin{tabular}{clcc}
\hline No. & \multicolumn{1}{c}{ Aspek yang diobservasi } & Prosentase & Ket \\
\hline 1. & $\begin{array}{l}\text { Pehamaman Guru tentang Kata KerjaOperasinal (KKO) dalam } \\
\text { pengembangan Indikator }\end{array}$ & $86 \%$ & \\
2. & Pehamaman Guru tentang Penggunaan KKO & $86 \%$ \\
3. Pehamaman Guru tentang ketepatan penulisan/ pengembangan & $76 \%$ \\
$\quad \begin{array}{l}\text { indikator } \\
\text { 4. Pehamaman Guru tentang sistematika pengembangan/ }\end{array}$ & $76 \%$ \\
\hline
\end{tabular}


Tabel 7. Prosentase Kemampuan Guru dalam Pengembangan Indikator siklus II

\begin{tabular}{clcc}
\hline No. & \multicolumn{1}{c}{ Aspek yang diobservasi } & Prosentase & Ket \\
\hline 1. & Indikator dikembangkan sesuai dengan karakteristik peserta didik & $70 \%$ & \\
2. & Indikator dikembangkan sesuai dengan karakteristik mata & $70 \%$ & \\
& pelajaran & $80 \%$ & \\
3. & Indikatordikembangkansesuaidengansatuanpendidikan & $80 \%$ & \\
4. & Indikator dikembangkan terukur dan dapat diobservasi & $80 \%$ & \\
5. & Indikator dikembangkan dengan Jelas dan tepat & \\
\hline
\end{tabular}

Tabel 8. Prosentase Aktivitas Guru dalam Kegiatan Pengembangan Indikator Siklus II

\begin{tabular}{|c|c|c|c|}
\hline No. & Aspek yang diobservasi & Prosentase & Ket \\
\hline 1. & Disiplin & $100 \%$ & \\
\hline 2. & TanggungJawab & $90 \%$ & \\
\hline 3. & Kerjasama & $90 \%$ & \\
\hline 4. & Antusias/serius & $100 \%$ & \\
\hline 5. & Keterlibatandalamdiskusi & $90 \%$ & \\
\hline
\end{tabular}

Tabel 9. Prosentase Pemahaman Guru tentang KKO dan Penggunaannya dalam Pengembangan Indikator

\begin{tabular}{clcc}
\hline No & \multicolumn{1}{c}{ Aspek yang diobservasi } & Siklus I & Siklus II \\
\hline 1. & $\begin{array}{l}\text { Pehamaman Guru tentang Kata KerjaOperasinal (KKO) dalam } \\
\text { pengembangan Indikator }\end{array}$ & $36 \%$ & $86 \%$ \\
2. & Pehamaman Guru tentang Penggunaan KKO & $40 \%$ & $86 \%$ \\
3. Pehamaman Guru tentang ketepatan penulisan/ pengembangan & $40 \%$ & $76 \%$ \\
$\quad \begin{array}{l}\text { indikator } \\
\text { Pehamaman Guru tentang sistematika pengembangan/ } \\
\text { penyusunan indikator }\end{array}$ & $28 \%$ & $76 \%$ \\
\hline
\end{tabular}

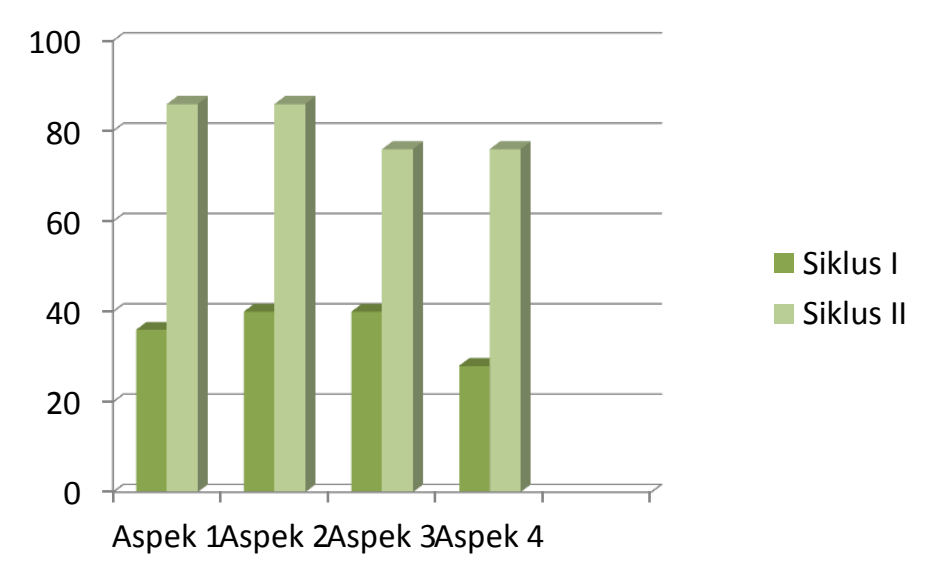

Gambar 1. Grafik Pemahaman Guru tentang KKO dan Penggunaannya dalam Pengembangan Indikator 
Tabel 10. Prosentase Pemahaman Guru tentang Pengembangan Indikator

\begin{tabular}{clcc}
\hline No & \multicolumn{1}{c}{ Aspek yang diobservasi } & Siklus I & Siklus II \\
. & & & \\
\hline 1. & Indikator dikembangkan sesuai dengan karakteristik peserta didik & $28 \%$ & $70 \%$ \\
$\mathbf{2 .}$ & Indikator dikembangkan sesuai dengan karakteristik mata & $30 \%$ & $70 \%$ \\
& pelajaran & $36 \%$ & $80 \%$ \\
3. & Indikatordikembangkansesuaidengansatuanpendidikan & $30 \%$ & $80 \%$ \\
4. & Indikator dikembangkan terukur dan dapat diobservasi & $30 \%$ & $80 \%$ \\
$\mathbf{5 .}$ & Indikator dikembangkan dengan Jelas dan tepat & & \\
\hline
\end{tabular}

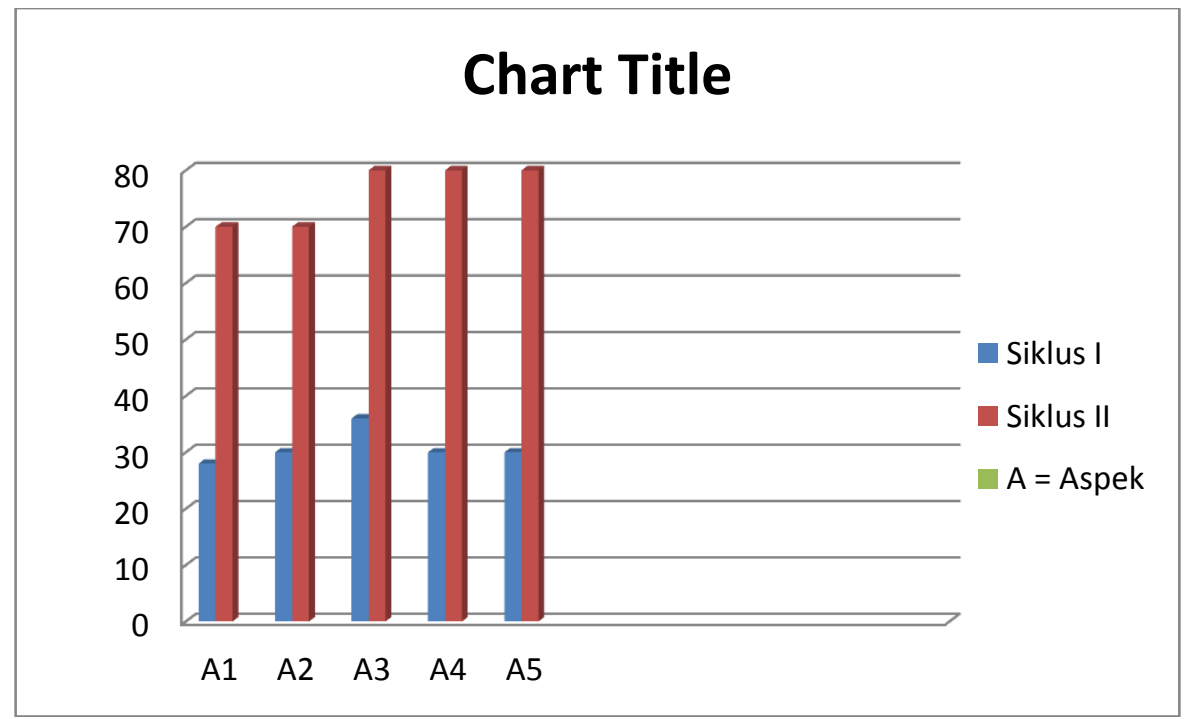

Gambar 2. Grafik Pemahaman Guru tentang Pengembangan Indikator

Tabel 11. Prosentase Aktivitas Guru dalam Kegiatan Pengembangan indikator

\begin{tabular}{clcc}
\hline No. & Aspek yang diobservasi & Siklus I & Siklus II \\
\hline $\mathbf{1 .}$ & Disiplin & $82 \%$ & $100 \%$ \\
2. & TanggungJawab & $82 \%$ & $90 \%$ \\
3. & Kerjasama & $78 \%$ & $90 \%$ \\
4. & Antusias/serius & $90 \%$ & $100 \%$ \\
$\mathbf{5 .}$ & Keterlibatandalamdiskusi & $76 \%$ & $90 \%$ \\
\hline
\end{tabular}

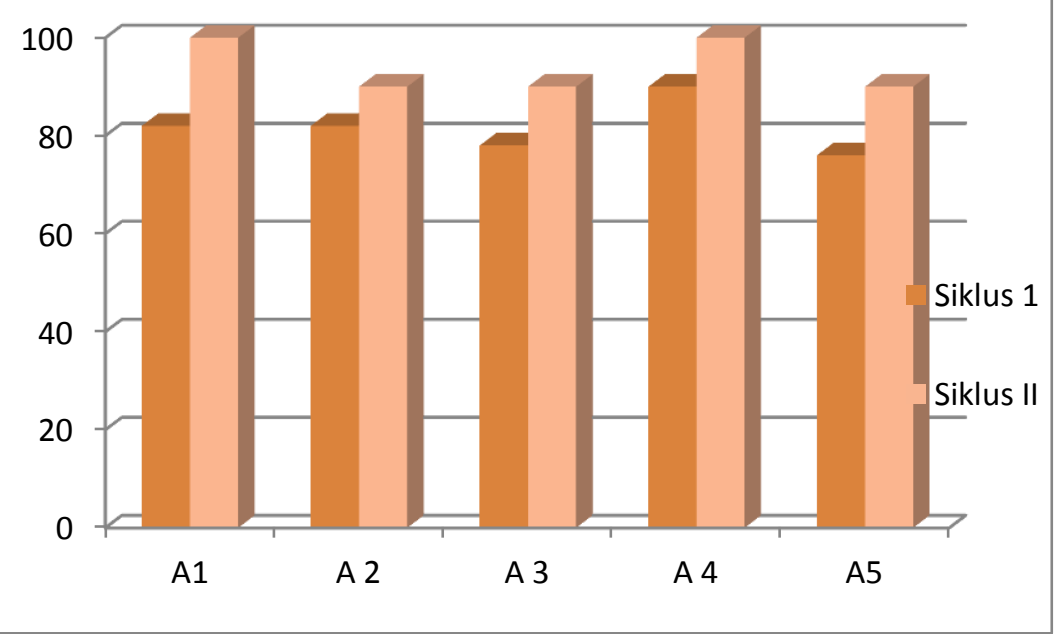

Gambar 3. Grafik rata-rata Prosentase Aktivitas Guru 


\section{KESIMPULAN}

Berdasarkan hasil pelaksanaan penelitian tentang peningkatan kualitas guru SD Negeri 49 Kota Ternate dalam pembuatan indikator pencapaian keberhasilan pada silabus melalui pos pelatihan sederhana tahun 2018, maka peneliti dapat menarik simpulan sebagai berikut:

1. Guru telah memahami tentang Kata Kerja Operasional (KKO) dan penggunaannya pada pembuatan indikator dalam penyusunan silabus.

2. Guru telah mampu membuat indikator dalam penyusunan silabus.

3. Terdapat peningkatan guru dalam pembuatan Indikator Pencapaian Keberhasilan pada kegiatan Pos Pelatihan Sederhana tersebut.

\section{DAFTAR PUSTAKA}

BSNP 2006, Panduan Penyusunan Kurikulum Tingkat Satuan Pendidikan Jenjang Pendidikan Dasar dan Pendidikan Menengah, Jakarta.

Dirjen PMPTK, 2007, Karya Tulis Ilmiah Laporan Hasil Penelitian, Pedoman

Penyusunan KTI pada Kegiatan Pengembangan Profesi Kepala Sekolah Sekolah.

Depdiknas (2007), Pedoman Supervisi Pengajaran, Jakarta

http://en.wikipedia.org/wiki/Bloom\%27s_Taxonomy,diunduh pada tanggal 21 April 2016

Hamalik, usman, 2006Pendidikan Guru Berdasarkan Pendekatan Kompetensi.Jakarta: Bumi Aksara,

Kita abati.blogspot.com.Permendiknas RI nomor 19 tahun 2005 tentang Standar Nasional Pendidikan.Diunduh pada tanggal 9 April 2016

Pendidik dan tenaga kependidikan.[ Online ] 15 April 2016 http://www.dinaspendidikan-parepare

Sindikker.dikti.go.id/dok/UU/UU20.2013. Sisdiknas pdf.Diunduh pada tanggal 12 April 2016

Sub Direktorat Dikmen Dirjen PMPTK, 2007, Metode dan Teknik Supervisi Bagi Kepala Sekolah Satuan Pendidikan, Kumpulan Materi Bintek Kepala Sekolah Sekolah.

Undang-undang Nomor 14 Tahun 2005, Tentang Guru dan Dosen

www.academia.educasi/Panduan Pengelolaan Kualitas KKG. bahan ajar Mandiri Pengelolaan kualitas KKG paket Pembelajaran bermutu. Diunduh pada tanggal 15 April 2018

www.goedreads.com. Kamus Umum Bahasa Indonesia.Pusat Pembinaan dan pengembangan Bahasa. Diunduh pada tanggal 17 April 2018

www.slindeshare.net/permendikbud-nomor-65-tahun 2013 tentang Standar Proses Pendidikan. Diunduh pada tanggal 10 April 2018 